\title{
NITROUS OXIDE EMISSION DEPENDING ON THE TYPE OF ELECTRON ACCEPTOR BY A DENITRIFYING PHOSPHORUS REMOVAL SLUDGE
}

TANG B.

WU G.*

WANG H.

GUAN Y.
Key Laboratory of Microorganism Application and Risk Control (MARC) of Shenzhen

Graduate School at Shenzhen, Tsinghua University

Shenzhen, 518055, Guangdong, China

*to whom all correspondence should be addressed:

e-mail: wu.guangxue@sz.tsinghua.edu.cn

Received: $23 / 11 / 2015$

Accepted: $15 / 02 / 2016$

Available online: $12 / 04 / 2016$

\section{ABSTRACT}

Denitrifying polyphosphate accumulating organisms (DNPAOs) are very promising for simultaneous nitrogen and phosphorus removal. While during denitrification, emission of a greenhouse gas, nitrous oxide $\left(\mathrm{N}_{2} \mathrm{O}\right)$, may occur. In this study, DNPAOs were enriched in a lab-scale reactor, and $\mathrm{N}_{2} \mathrm{O}$ emission was examined under different electron acceptor conditions. During the anoxic phase, with the uptake of phosphorus, denitrification of nitrate nitrogen $\left(\mathrm{NO}_{3}-\mathrm{N}\right)$ was observed without the accumulation of nitrite nitrogen $\left(\mathrm{NO}_{2}-\mathrm{N}\right)$. In general, a very low amount of $\mathrm{N}_{2} \mathrm{O}$ was produced with nitrate as the electron acceptor, independent of the applied different nitrate concentrations. However, with nitrite as the electron acceptor, a much higher $\mathrm{N}_{2} \mathrm{O}$ emission occurred. The $\mathrm{N}_{2} \mathrm{O}$ emission factor to the denitrified $\mathrm{NO}_{2}-$ $\mathrm{N}$ was $6.2 \%, 5.3 \%$ and $4.9 \%$ at the initial $\mathrm{NO}_{2}-\mathrm{N}$ concentration of 10,20 and $40 \mathrm{mg} \mathrm{l}^{-1}$, respectively. In addition, a much higher $\mathrm{N}_{2} \mathrm{O}$ emission occurred with the co-existence of $\mathrm{NO}_{3}-\mathrm{N}$ and $\mathrm{NO}_{2}-\mathrm{N}$. The initial organic carbon concentration had no significant effect on $\mathrm{N}_{2} \mathrm{O}$ emission with $\mathrm{NO}_{3}-\mathrm{N}$ as the electron acceptor. When stored organic carbon by DNPAOs was used as the electron donor, $\mathrm{N}_{2} \mathrm{O}$ emission was mainly dependent on the electron acceptor.

Keywords: nitrous oxide, denitrifying polyphosphate accumulating organisms, nitrite, intracellular stored organic carbon

\section{Introduction}

Denitrifying phosphate removal processes are very promising for simultaneous nitrogen and phosphorus removal, especially for treating organic carbon limited wastewater. It possesses characteristics of both denitrification and enhanced biological phosphorus removal. While during denitrification, emission of a greenhouse gas, nitrous oxide $\left(\mathrm{N}_{2} \mathrm{O}\right)$, may occur under certain conditions, such as high nitrite concentrations, low organic carbon to nitrogen ratios and low dissolved oxygen concentrations. $\mathrm{N}_{2} \mathrm{O}$ has a very high greenhouse effect potential, i.e., 300 times that of carbon dioxide (IPCC, 2001). Therefore, a small amount of $\mathrm{N}_{2} \mathrm{O}$ emission may cause a significant greenhouse effect. In addition, $\mathrm{N}_{2} \mathrm{O}$ is also an ozone depeletion substance and should be carefully controlled. From the view of sustainable development, avoidance of secondary pollutants during wastewater treatment should be carried out. Therefore, it is necessary to examine $\mathrm{N}_{2} \mathrm{O}$ emission characteristics during biological nitrogen removal or during simultaneous biological nitrogen and phosphorus removal.

During denitrifying phosphate removal, microbial communities such as denitrifying polyphosphate accumulating organisms (DNPAOs), carry out denitrification using intracellular stored organic carbon (such as polyhydroxybutyrate, PHB) as the electron donor and nitrate or nitrite as the electron acceptor. 
There are contrary results about the effect of intracellular organic carbon on the $\mathrm{N}_{2} \mathrm{O}$ emission and the mechanism is still unclear (Kampschreur et al., 2009). Zeng et al. (2003) and Lemaire et al. (2006) found that a high $\mathrm{N}_{2} \mathrm{O}$ emission (for example half of denitrified nitrate was converted to $\mathrm{N}_{2} \mathrm{O}$ ) occurred in anaerobic and aerobic processes, especially with activities of glycogen accumulating organisms (GAOs). The reason could be due to that the utilization rate of PHB was slow, which might cause a carbon limitation condition and induce a high $\mathrm{N}_{2} \mathrm{O}$ emission (Meyer et al., 2005; Wang et al., 2011b; Zhou et al., 2013). In addition, during denitrification, a high accumulation of nitrite may also induce $\mathrm{N}_{2} \mathrm{O}$ emission, especially when denitrifying activities were inhibited (Li et al., 2013b; Zhou et al., 2008; Wang et al., 2011a). Wu et al. (2013) obtained that when PHB was used as the organic carbon for denitrification, a high $\mathrm{N}_{2} \mathrm{O}$ emission occurred when nitrite was coexisted. When the intracellular organic carbon is used for denitrification, whether the intracellular organic carbon itself or the existence of nitrite contributed to $\mathrm{N}_{2} \mathrm{O}$ emission has not been clearly clarified (Kampschreur et al., 2009). Therefore, it is necessary to examine effect of different electron acceptors on $\mathrm{N}_{2} \mathrm{O}$ emission during denitrification.

In this study, DNPAOs were enriched in a lab-scale reactor, and then characteristics of $\mathrm{N}_{2} \mathrm{O}$ emission during denitrifying phosphorus removal was examined under different electron acceptor conditions.

\section{Materials and methods}

\subsection{Denitrifying phosphate removal process}

A sequencing batch reactor (SBR) with a working volume of 6 litres was operated at $25^{\circ} \mathrm{C}$. The SBR had three cycles per day and each cycle comprised the following phases: fill (10 $\mathrm{min})$, anaerobic (110 $\mathrm{min})$, anoxic (180 $\mathrm{min})$, aerobic $(120 \mathrm{~min})$, settle $(40 \mathrm{~min})$ and draw/idle $(20 \mathrm{~min})$. In each cycle, 3 litres of treated wastewater were exchanged with a new batch of synthetic wastewater. The reactor was constantly stirred with a mixer during the fill, anaerobic and aerobic phases. During the aerobic phase, air was supplied with an air diffuser located at the bottom of the reactor. During the anoxic phase, nitrate stock solution was dosed to achieve the initial nitrate nitrogen $\left(\mathrm{NO}_{3}-\mathrm{N}\right)$ concentration of $30 \mathrm{mg} \mathrm{l}^{-1}$. Once a day, $400 \mathrm{ml}$ of mixed liquor was withdrawn from the reactor just before the end of the aerobic phase, resulting in a solids retention time (SRT) of around 15 days if no solids loss occurred during the settling phase.

The components of the synthetic wastewater contained sodium acetate, yeast extract, $\mathrm{NH}_{4} \mathrm{Cl}, \mathrm{Na}_{2} \mathrm{HPO}_{4}$, $\mathrm{MgSO}_{4} \cdot 7 \mathrm{H}_{2} \mathrm{O}, \mathrm{CaCl}_{2} \cdot 6 \mathrm{H}_{2} \mathrm{O}$ and trace elements. The influent chemical oxygen demand (COD) was around $400 \mathrm{mg} \mathrm{l}^{-1}$, ammonium nitrogen $\left(\mathrm{NH}_{4}-\mathrm{N}\right)$ of $15 \mathrm{mg} \mathrm{l}^{-1}$ and orthophoshate $\left(\mathrm{PO}_{4}-\mathrm{P}\right)$ of $15 \mathrm{mg} \mathrm{l}^{-1}$. The reactor was seeded with activated sludge taken from a Wastewater Treatment Plant in Shenzhen, China.

\subsection{Batch denitrification experiments}

Batch experiments with replications were carried out to examine effects of electron acceptors, initial nitrite nitrogen $\left(\mathrm{NO}_{2}-\mathrm{N}\right)$ concentrations and initial PHB concentrations on $\mathrm{N}_{2} \mathrm{O}$ emission. Average result data from replications were presented. The batch reactors were made from $500 \mathrm{ml}$ capped glass flasks, each with three ports on the cap, one for liquid sampling, one for gas sampling, and the other for gas balance.

For the effect of electron acceptors, activated sludge mixed liquor was withdrawn from the SBR at the end of the anaerobic phase, and then different concentrations $\left(\mathrm{NO}_{3}-\mathrm{N}\right.$ of 15,30 and $60 \mathrm{mg} \mathrm{l}^{-1}$, $\mathrm{NO}_{2}-\mathrm{N}$ of 10,20 and $40 \mathrm{mg} \mathrm{l}^{-1}$, and $\mathrm{NO}_{3}-\mathrm{N} / \mathrm{NO}_{2}-\mathrm{N}$ of $30 / 5,30 / 10,30 / 20 \mathrm{mg} \mathrm{l}^{-1}$, respectively) of electron acceptors were added for commencing the experiment. For examining the effect of PHB on $\mathrm{N}_{2} \mathrm{O}$ emission, the activated sludge was taken from the SBR at the end of the aerobic phase, and then different concentrations of $\operatorname{COD}\left(50,100\right.$ and $\left.200 \mathrm{mg} \mathrm{l}^{-1}\right)$ was added for accumulating PHB under ananerobic conditions. After that, $\mathrm{NO}_{3}-\mathrm{N}$ of $30 \mathrm{mg} \mathrm{l}^{-1}$ was added to initiate the experiment. In all batch experiments, samples (both liquid and gas samples) were taken at intervals to test $\mathrm{NO}_{2}-\mathrm{N}$ and $\mathrm{NO}_{3}-\mathrm{N}$ for liquid samples, and $\mathrm{N}_{2} \mathrm{O}$ for gas samples. 


\subsection{Analytical methods}

$\mathrm{NO}_{2}-\mathrm{N}, \mathrm{NO}_{3}-\mathrm{N}$, suspended solids (SS), volatile suspended solids (VSS) and $\mathrm{NH}_{4}-\mathrm{N}$ were determined according to standard methods (APHA, 1995). The PHB concentration was detected by the modified HPLC method (Karr et al., 1983; Rodgers and $\mathrm{Wu}, 2010$ ) with crotonic acid used for calibration. $\mathrm{N}_{2} \mathrm{O}$ was detected according to Wu et al. (2013).

\section{Results and discussion}

The system had been operated for more than 6 months and a very good DNPAOs activities had been obtained. The fraction of DNPAOs to PAOs was around $87 \%$ calculated from the aerobic and anoxic $\mathrm{PO}_{4}-\mathrm{P}$ uptake experiments (data not shown), showing that DNPAOs were successfully enriched inside the system. Dynamics of oxidized nitrogen and phosphorus are shown in Figure 1. During the anaerobic phase, a high amount of $\mathrm{PO}_{4}-\mathrm{P}$ was released, during the anoxic phase, $\mathrm{PO}_{4}-\mathrm{P}$ was taken up, and during the aerobic phase, $\mathrm{PO}_{4}-\mathrm{P}$ was further taken up. During the anoxic phase, with the uptake of $\mathrm{PO}_{4}-\mathrm{P}$, denitrification of nitrate was observed without the accumulation of nitrite. In the study of Oehmen et al. (2010), similar phenomenon was also reported but was not emphasized. However, the phenomenon was different from other previous studies in DNPAO systems, where during the anoxic phase, denitrification of nitrate was accompanied with the nitrite accumulation (such as Li et al., 2013b and Wang et al., 2011a).

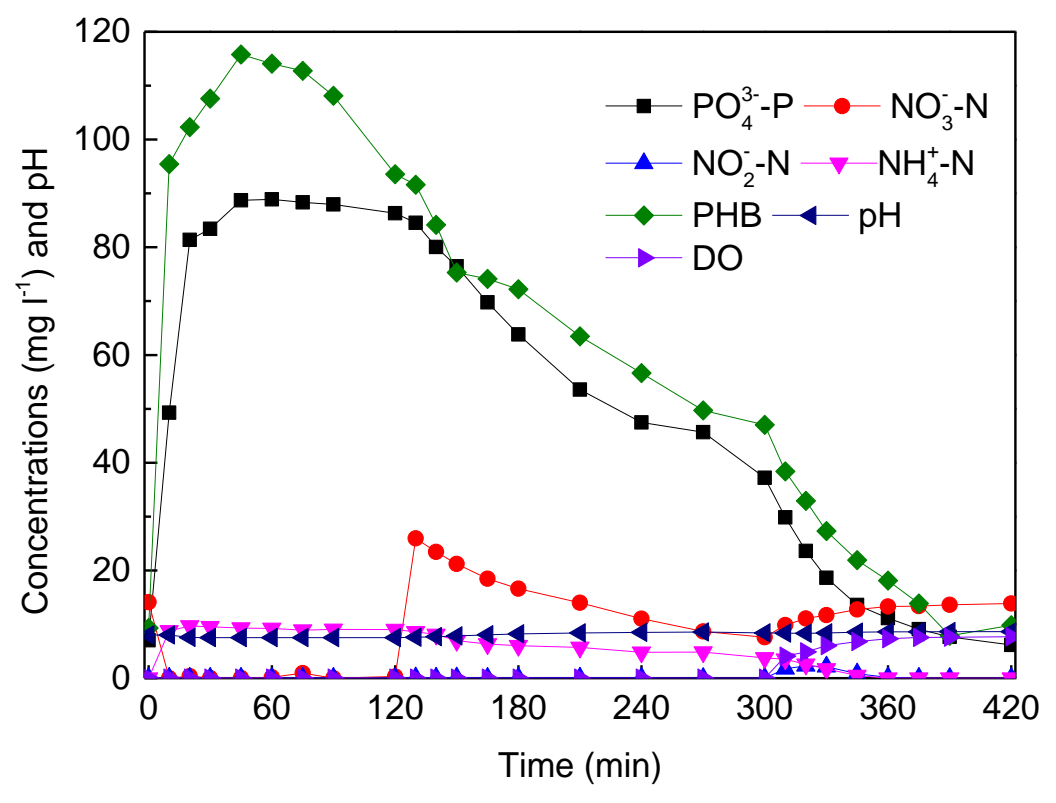

Figure 1. Dynamics of parameters within a typical SBR cycle.

Batch denitrification of nitrate or nitrite for DNPAOs under different oxidized nitrogen (NOx-N) concentrations are shown in Figure 2. In general, a very low amount of $\mathrm{N}_{2} \mathrm{O}$ was produced with $\mathrm{NO}_{3}-\mathrm{N}$ as the electron acceptor, with the $\mathrm{N}_{2} \mathrm{O}$ emission factor to the denitrified $\mathrm{NO}_{3}-\mathrm{N}$ of below $0.12 \%$. However, with $\mathrm{NO}_{2}-\mathrm{N}$ as the electron acceptor, a much higher $\mathrm{N}_{2} \mathrm{O}$ emission occurred. At the initial $\mathrm{NO}_{2}-\mathrm{N}$ concentration of $10 \mathrm{mg} \mathrm{l}^{-1}, \mathrm{~N}_{2} \mathrm{O}$ emission occurred during the initial $30 \mathrm{~min}$ of the batch experiment, and then decreased with the complete consumption of $\mathrm{NO}_{2}-\mathrm{N}$. While under the initial $\mathrm{NO}_{2}-\mathrm{N}$ concentration of 20 and $40 \mathrm{mg} \mathrm{l}^{-1}, \mathrm{~N}_{2} \mathrm{O}$ emission occurred during the whole batch experiment period. The $\mathrm{N}_{2} \mathrm{O}$ emission factor to the denitrified $\mathrm{NO}_{2}-\mathrm{N}$ was $6.2 \%, 5.3 \%$ and $4.9 \%$ at the initial $\mathrm{NO}_{2}-\mathrm{N}$ concentration of 10,20 and $40 \mathrm{mg} \mathrm{l}^{-1}$, respectively. In addition, the $\mathrm{NO}_{2}-\mathrm{N}$ reduction rate decreased with increasing $\mathrm{NO}_{2}-\mathrm{N}$ concentrations, with values of $11.1,8.7$ and $7.7 \mathrm{mg} \mathrm{g} \mathrm{VSS}^{-1} \mathrm{~h}^{-1}$ at the $\mathrm{NO}_{2}-\mathrm{N}$ concentrations of 10,20 and $40 \mathrm{mg} \mathrm{l}^{-1}$, respectively. 

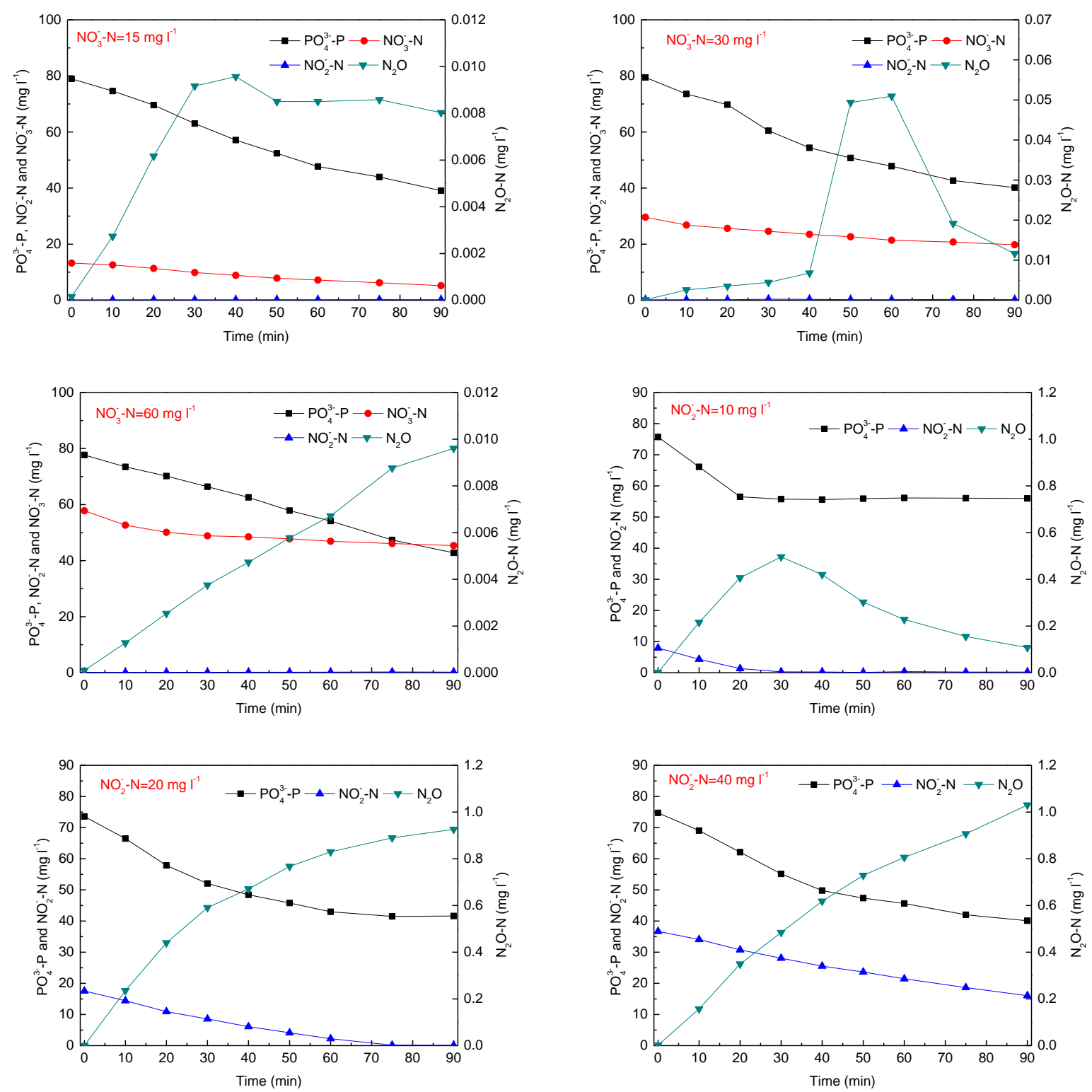

Figure 2. $\mathrm{N}_{2} \mathrm{O}$ emission under different electron acceptor concentrations

Batch denitrification of DNPAOs under different $\mathrm{NO}_{2}-\mathrm{N}$ concentrations with the co-existence of $\mathrm{NO}_{3}-\mathrm{N}$ are shown in Figure 3. Similar to the effect of $\mathrm{NO}_{2}-\mathrm{N}$ alone, a high $\mathrm{N}_{2} \mathrm{O}$ emission was observed. The $\mathrm{N}_{2} \mathrm{O}$ emission factor to the denitrified $\mathrm{NO}_{x}-\mathrm{N}$ was $7.9 \%, 8.0 \%$ and $10.8 \%$ at the initial $\mathrm{NO}_{2}-\mathrm{N}$ concentration of 5,10 and $20 \mathrm{mg} \mathrm{l}^{-1}$ with the co-existence of $30 \mathrm{mg} \mathrm{l}^{-1} \mathrm{NO}_{3}-\mathrm{N}$, respectively. The $\mathrm{NO}_{3}-\mathrm{N}$ reduction rate was 4.6, 5.6 and $6.4 \mathrm{mg} \mathrm{g} \mathrm{VSS}^{-1} \mathrm{~h}^{-1}$ at the initial $\mathrm{NO}_{2}-\mathrm{N}$ concentration of 5, 10 and $20 \mathrm{mg} \mathrm{l}^{-1}$, while the NOx-N reduction rate was around $6.0 \mathrm{mg} \mathrm{g} \mathrm{VSS}^{-1} \mathrm{~h}^{-1}$ under all conditions. For $\mathrm{NO}_{2}-\mathrm{N}$, it was reduced under the initial $\mathrm{NO}_{2}-\mathrm{N}$ concentration of 5 and $10 \mathrm{mg} \mathrm{l}^{-1}$, while was produced at the initial $\mathrm{NO}_{2}-\mathrm{N}$ concentration of $20 \mathrm{mg} \mathrm{l}^{-1}$.

Batch denitrification of DNPAOs under different initial PHB concentrations with $\mathrm{NO}_{3}-\mathrm{N}$ as the electron acceptor are shown in Figure 4. Similar to the effect of $\mathrm{NO}_{3}-\mathrm{N}$ alone, there was not much $\mathrm{N}_{2} \mathrm{O}$ emission, with the $\mathrm{N}_{2} \mathrm{O}$ emission factor to the denitrified $\mathrm{NO}_{3}-\mathrm{N}$ also below $0.12 \%$ under all conditions. This result indicated that the carbon to nitrogen ratio had no significant effect on $\mathrm{N}_{2} \mathrm{O}$ emission for the enriched DNPAOs when $\mathrm{NO}_{3}-\mathrm{N}$ was used as the electron acceptor. 

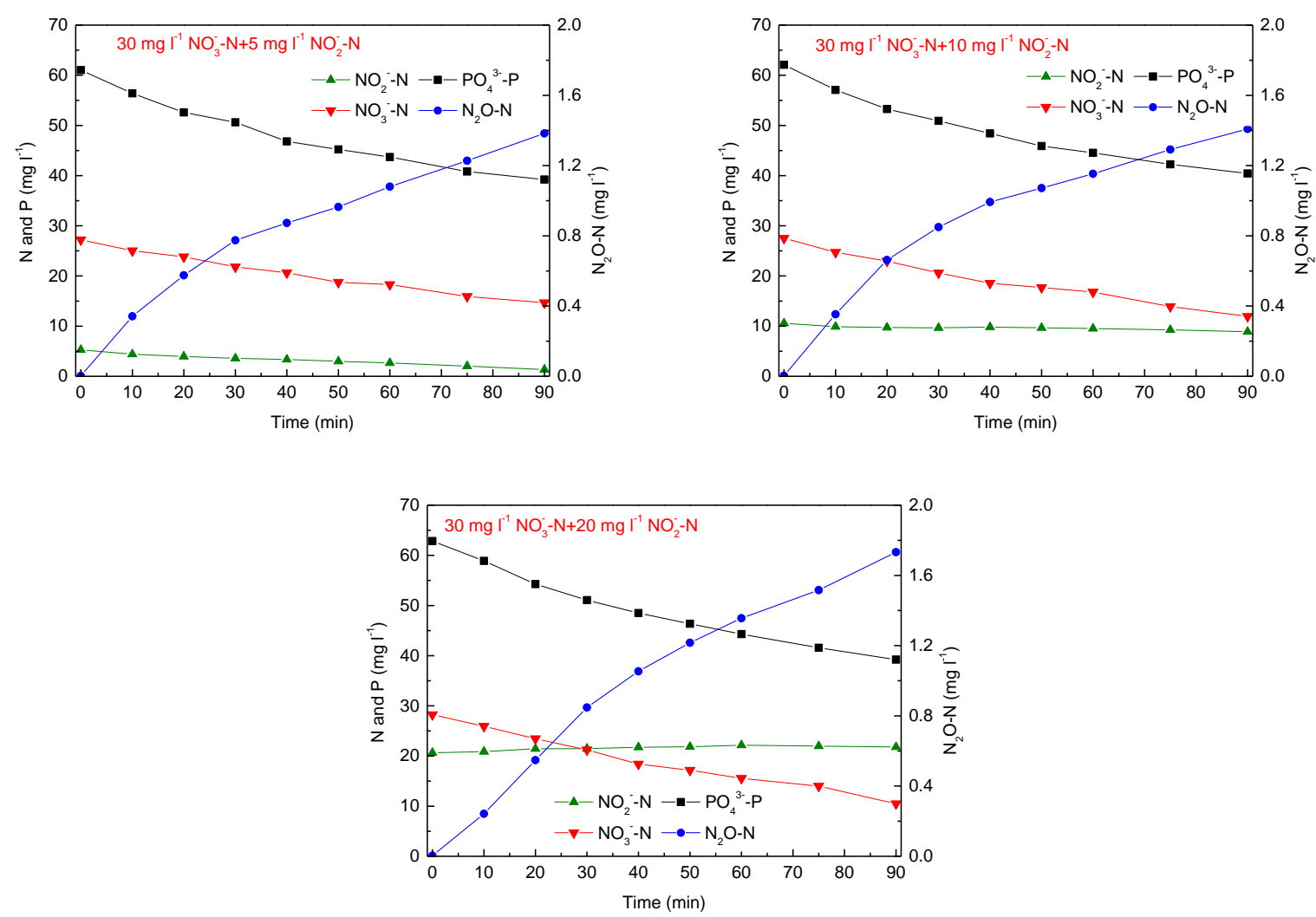

Figure 3. $\mathrm{N}_{2} \mathrm{O}$ emission under different $\mathrm{NO}_{2}-\mathrm{N}$ concentrations with the co-existence of nitrate
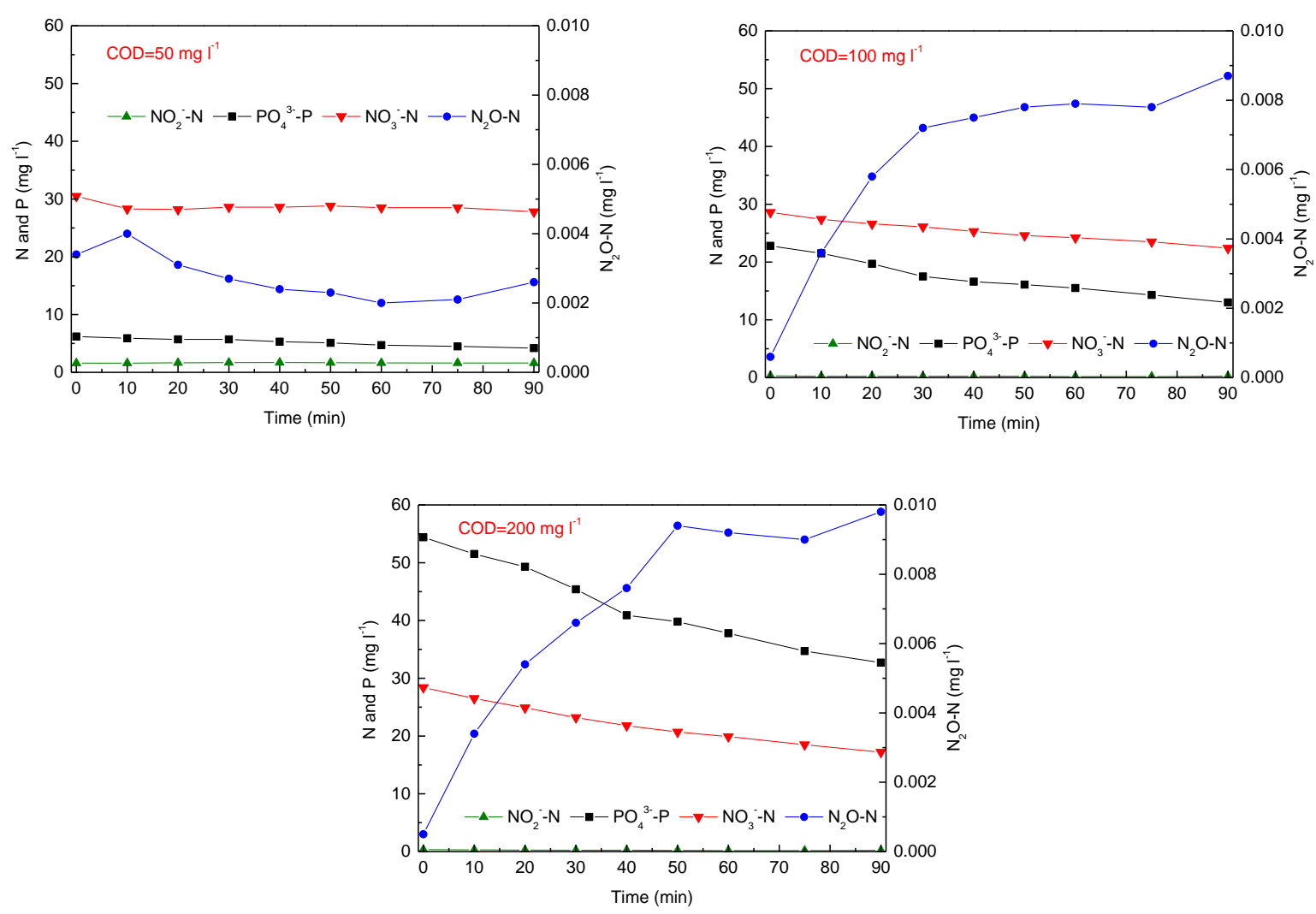

Figure 4. $\mathrm{N}_{2} \mathrm{O}$ emission under different initial organic carbon concentrations 
This study indicated that at least two types of metabolic modes were presented for DNPAOs. One was denitrifying nitrate with the accumulation of nitrite and the other was without the accumulation of nitrite. Special attention should be given when examination of DNPAO systems. For GAOs dominated denitrifying systems, there are also existing similar denitrifying modes. In the study of Lemaire et al. (2006), under batch experiments with nitrate or nitrite as the electron acceptor, $\mathrm{N}_{2} \mathrm{O}$ emission occurred under both conditions even when nitrate was used as the electron acceptor and no $\mathrm{NO}_{2}-\mathrm{N}$ accumulation, with the $\mathrm{N}_{2} \mathrm{O}$ emission factor of $77 \%$ for nitrite and $26 \%$ for nitrate as the electron acceptor, respectively. Therefore, for $\mathrm{PAOs}$ or $\mathrm{GAOs}$, the microbial community was an important factor inducing $\mathrm{N}_{2} \mathrm{O}$ emission even with no $\mathrm{NO}_{2}-\mathrm{N}$ accumulation. In addition, the high $\mathrm{N}_{2} \mathrm{O}$ emission might also due to low diversity of denitrifiers (Lemaire et al., 2006).

When PHB was used as the electron donor, $\mathrm{N}_{2} \mathrm{O}$ emission was dependent on the electron acceptor. When nitrate was used, there was not much $\mathrm{N}_{2} \mathrm{O}$ emission, while when nitrite was used, a high $\mathrm{N}_{2} \mathrm{O}$ emission occurred. Therefore, PHB was not the intrinsic reason causing $\mathrm{N}_{2} \mathrm{O}$ emission during denitrification. In addition, the carbon to nitrogen ratios also had no significant effect on $\mathrm{N}_{2} \mathrm{O}$ emission with nitrate as the electron acceptor. Wang et al. (2011b) showed that polyhydroxyalkanoate (PHA) degradation regulated the denitrifying phosphorus removal and $\mathrm{N}_{2} \mathrm{O}$ production, and shorten anaerobic reaction duration from 90 min to 60 min could reduce the $\mathrm{N}_{2} \mathrm{O}$ emission; in this system, denitrifying nitrate was accompanied with nitrite accumulation; $\mathrm{N}_{2} \mathrm{O}$ emission decreased with increasing the PHA concentration. Zhou et al. (2013) compared DNPAOs denitrification utilizing intracellular organic carbon and external organic carbon, the $\mathrm{N}_{2} \mathrm{O}$ emission was high at low carbon to nitrogen ratios with external organic carbons, and there was no much difference at high carbon to nitrogen ratios; in addition, PHA consumption was shown to be the limiting step for $\mathrm{N}_{2} \mathrm{O}$ reduction, however, in this study, only the effect of $\mathrm{NO}_{2}-\mathrm{N}$ was examined. Meyer et al. (2005) obtained that $\mathrm{N}_{2} \mathrm{O}$ was a product of denitrification with stored PHA as the organic carbon.

As to the effect of nitrite, there are several opinions. The first reason could be due to that the accumulated $\mathrm{NO}_{2}-\mathrm{N}$ induced a high $\mathrm{N}_{2} \mathrm{O}$ emission. During denitrification, acetate could induce a high accumulation of $\mathrm{NO}_{2}-\mathrm{N}$ and further a high emission of $\mathrm{N}_{2} \mathrm{O}$, with the proportion of $\mathrm{N}_{2} \mathrm{O}$ production to the applied influent nitrate of 74\% (Adouani et al., 2010). Wang et al. (2011a) obtained that nitrite accumulation was up to 20 $\mathrm{mg}^{-1}$ during denitrifying phosphorus removal and the $\mathrm{N}_{2} \mathrm{O}$ emission factor to the removed $\mathrm{NO}_{3}-\mathrm{N}$ was $7.77 \%$, while when the organic carbon was switched to propionate or acetate/propionate, the $\mathrm{N}_{2} \mathrm{O}$ emission factor increased by 0.77 and 1.72 times. The second reason could be due to that the inhibition induced by $\mathrm{NO}_{2}-\mathrm{N}$ or free nitrous acid (FNA). Zhou et al. (2008) obtained that the degree of inhibition of nitrite on DNPAOs was observed to be correlated much strongly with the FNA concentration than with the nitrite concentration, suggesting that FNA, rather than nitrite, was likely to be the true inhibitor on $\mathrm{N}_{2} \mathrm{O}$ reduction. Fifty percent inhibition was observed at a FNA concentration of 0.0007-0.001 mg $\mathrm{HNO}_{2}-\mathrm{N}$ $\mathrm{I}^{-1}$ (equivalent to approximately 3-4 $\mathrm{mg} \mathrm{NO}_{2}-\mathrm{N} \mathrm{I}^{-1}$ at $\mathrm{pH}$ 7), while complete inhibition occurred when the FNA concentration was greater than $0.004 \mathrm{mg} \mathrm{HNO}_{2}-\mathrm{N} \mathrm{I}^{-1}$. The results also suggest that the inhibition on $\mathrm{N}_{2} \mathrm{O}$ reduction was not due to the electron competition between $\mathrm{N}_{2} \mathrm{O}$ and $\mathrm{NO}_{2}-\mathrm{N}$ reductases. The inhibition was found to be reversible, with the rate of recovery independent of the duration of the inhibition, but dependent on the concentration of FNA the biomass was exposed to during the inhibition period. A higher FNA concentration caused slower recovery. The last reason could be due to the competetion among the denitrifying reductases. Li et al. (2013b) obtained that $\mathrm{N}_{2} \mathrm{O}$ generation accounted for $0.41 \%$ of the total nitrogen removal in denitrifying phosphorus removal process and the weak competition of $\mathrm{N}_{2} \mathrm{O}$ reductase for electrons and the high nitrite accumulation were the two main reasons causing $\mathrm{N}_{2} \mathrm{O}$ generation. The same group also obtained that $\mathrm{N}_{2} \mathrm{O}$ emission increased with increasing the organic carbon concentrations, which could be due to that a high concentration of organic carbon induced a high production of PHA and consequently a high concentration of accumulated nitrite (Li et al. 2013a).

Therefore, due to the diversity of DNPAOs, different metabolism modes may be existed under different conditions. When examining $\mathrm{N}_{2} \mathrm{O}$ emission in DNPAOs systems, effect of intracellular organic carbon, 
nitrite and also organic carbon to nitrogen ratios, should be carefully analyzed with the consideration of acclimated DNPAOs.

\section{Conclusions}

DNPAOs were enriched in a lab-scale reactor, and a new phenomenon was examined. When stored organic carbon of DNPAOs was used as the electron donor, $\mathrm{N}_{2} \mathrm{O}$ emission was depended on the electron acceptor. When nitrate was used, there was not much $\mathrm{N}_{2} \mathrm{O}$ emission, while when nitrite was used, a high $\mathrm{N}_{2} \mathrm{O}$ emission potential occurred. In addition, when nitrate and nitrite existed simultaneously, $\mathrm{N}_{2} \mathrm{O}$ emission was higher than that when only nitrite existed. Therefore, PHA was not the intrinsic reason causing $\mathrm{N}_{2} \mathrm{O}$ emission during denitrification for the acclimated DNPAOs and the electron acceptor played an important role in $\mathrm{N}_{2} \mathrm{O}$ emission.

\section{Acknowledgements}

This research was supported by the National Natural Science Foundation of China (No: 51108242) and the Shenzhen Overseas High-Level Talents Innovation Funds Peacock Plan Project (KQCX20120814155347053).

\section{References}

APHA. (1995), Standard methods for the examination of water and wastewater, American Public Health Association, Washington D.C.

Beun J.J., Dircks K., Van Loosdrecht M.C.M and Heijnen J.J. (2002), Poly- $\beta$-hydroxybutyrate metabolism in dynamically fed mixed microbial cultures, Water Research, 36, 1167-1180.

IPCC. (2001) Climate Change 2001: the scientific basis, Cambridge University Press, Cambridge, U.K.

Kampschreur M.J., Temmink H., Kleerebezem R., Jetten M.S.M. and Van Loosdrecht M.C.M. (2009), Nitrous oxide emission during wastewater treatment, Water Research, 43, 4093-4103.

Karr D.B., Waters J.K. and Emerich D.W. (1983), Analysis of poly- $\beta$-hydroxybutyrate in Rhizobium japonicum bacteroids by ion-exclusion high-pressure liquid chromatography and UV detection, Applied and Environmental Microbiology, 46(6), 1339-1344.

Lemaire R., Meyer R., Taske A., Crocetti G.R., Keller J. and Yuan Z. (2006), Identifying causes for $\mathrm{N}_{2} \mathrm{O}$ accumulation in a lab-scale sequencing batch reactor performing simultaneous nitrification, denitrification and phosphorus removal, Journal of Biotechnology, 122, 62-72.

Li C., Wang T., Zheng N., Zhang J., Ngo H.H., Guo W. and Liang S. (2013a), Influence of organic shock loads on the production of $\mathrm{N}_{2} \mathrm{O}$ in denitrifying phosphorus removal process, Bioresource Technology, 141, 160-166.

Li C., Zhang J., Liang S., Ngo H.H., Guo W., Zhang Y. and Zou Y. (2013b), Nitrous oxide generation in denitrifying phosphorus removal processes: main causes and control measures, Environmental Science and Pollution Research, 20, 5353-5360.

Meyer R.L., Zeng R.J., Giugliano V. and Blackall L.L. (2005), Challenges for simultaneous nitrification, denitrification, and phosphorus removal in microbial aggregates: mass transfer limitation and nitrous oxide production, FEMS Microbiology Ecology, 52, 329-338.

Oehmen A., Carvalho G., Freitas F. and Reis M.A.M. (2010), Assessing the abundance and activity of denitrifying polyphosphate accumulating organisms through molecular and chemical techniques, Water Science and Technology, 61(8), 2061-2068.

Rodgers M. and Wu G. (2010), Production of polyhydroxybutyrate by activated sludge performing enhanced biological phosphorus removal, Bioresource Technology, 101(3), 1049-1053.

Smolders G.J.F., Van der Meij J., Van Loosdrecht M.C.M. and Heijnen J.J. (1994), Model of the anaerobic metabolism of the biological phosphorus removal process: stoichiometry and $\mathrm{pH}$ influence, Biotechnology and Bioengineering, 43(6), 461-470.

Wang Y., Geng J., Guo G., Wang C. and Liu S. (2011a), N2O production in anaerobic/anoxic deniyrifying phosphorus removal processes: the effects of carbon sources shock, Chemical Engineering Journal, 172, 999-1007. 
Wang Y., Geng J., Ren Z., He W., Xing M., Wu M. and Chen S. (2011b), Effect of anaerobic reaction time on denitrifying phosphorus removal and $\mathrm{N}_{2} \mathrm{O}$ production, Bioresource Technology, 102, 5674-5684.

Wu G., Zhai X., Jiang C. and Guan Y. (2013), Effect of ammonium on nitrous oxide emission during denitrification with different electron donors, Journal of Environmental Sciences, 25(6), 1131-1138.

Zeng R.J., Lemaire R., Yuan Z., and Keller J. (2003), Simultaneous nitrification, denitrification, and phosphorus removal in a lab-scale sequencing batch reactor, Biotechnology and Bioengineering, 84, 170-178.

Zhou Y., Lim M., Harjono S. and Ng W.J. (2012), Nitrous oxide emission by denitrifying phosphorus removal culture using polyhydroxyalkanoates as carbon source, Journal of Environmental Sciences, 24(9), 1616-1623.

Zhou Y., Pijuan M., Zeng R.J. and Yuan Z. (2008), Free nitrous acid inhibition on nitrous oxide reduction by a denitrifying-enhanced biological phosphorus removal sludge, Environmental Science and Technology, 42, 8260-8265. 